\title{
Marshall McLuhan, cem anos depois
}

É com grande satisfação que apresentamos o terceiro número da E-Compós 2011, dedicado à obra de Marshall McLuhan, no ano em que se comemora em todo o mundo o centenário de seu nascimento. Um dos autores mais polêmicos da história da Comunicação como campo científico, autor de frases célebres e promotor de debates que se estendem até os dias de hoje, 0 canadense Herbert Marshall McLuhan (1911-1980) deixou uma marca indelével no pensamento do século XX. Um dos pioneiros a tomar os meios de comunicação e seus efeitos na sociedade como objeto de pesquisa, muitas das ideias de McLuhan foram fundamentais para o estabelecimento da comunicação como campo acadêmico. Após um período de ostracismo em que suas ideias "saíram de moda", o surgimento e a difusão mundial da Internet, em fins dos anos 1990, trouxe novamente à cena a ideia de uma "aldeia global", fazendo com que McLuhan passasse a ser considerado uma espécie de "profeta", que não foi propriamente compreendido em seu tempo. Nem exaltando ingenuamente, nem criticando cegamente, pretendemos com este número trazer para nossos/as leitores/as um painel de posições contemporâneas sobre a vida e a obra deste intelectual tão importante em nosso campo de pesquisa. 
Temos neste número dois autores convidados, especialistas de renome mundial na obra de McLuhan: Lance Strate, professor da Universidade Fordham, nos Estados Unidos, com o texto The Fall of Nations: The Fate of Social Systems in the New Media Environment, em que analisa, à luz das teorias de McLuhan, o impacto dos novos ambientes midiáticos na organização mundial contemporânea. Outro texto de um ilustre convidado é 0 artigo Figure/Ground: cracking the McLuhan code, de Robert K. Logan, professor na Universidade de Toronto, amigo e colaborador pessoal de Marshall McLuhan, no qual apresenta uma chave de leitura para compreender os escritos de McLuhan, frequentemente acusados de serem de difícil compreensão, a noção de "figura/fundo" (figure/ground), à qual McLuhan se refere diversas vezes em cartas e escritos pouco conhecidos no Brasil.

Além destes dois textos, esta edição apresenta os seguintes artigos: McLuhan, Burawoy, McLuhan, de Gregory Sandstrom, que relaciona a obra de Marshall McLuhan à de Michael Burawoy e Eric McLuhan, particularmente a partir da noção de "extensão humana"; em Telégrafo, Televisão e Twitter, de Caroline Casali e Marco Bonito, estas três tecnologias da comunicação são pensadas articulando a teoria de McLuhan à teoria da midiatização; em Imagens da indústria automotiva para consumo, de Vander Casaqui, a teoria de McLuhan acerca do automóvel como extensão humana é explorada a propósito do discurso publicitário sobre automóveis; finalmente, 0 artigo Sensus communis, de Irene Machado, explora as articulações metodológicas e epistemológicas construídas por McLuhan na compreensão humana através da percepção e da cognição no ambiente acústico das mídias.

Complementam esta edição uma resenha do livro Estendendo McLuhan: da aldeia à teia global - comunicação, memória e 
tecnologia, de Vinicius Pereira, e uma entrevista histórica com o próprio Marshall McLuhan, realizada em 1972 pela revista francesa L'Express, traduzida em português pela Revista ALCEU e republicada na E-Compós graças à gentil concessão da Editora PUC-Rio, a quem agradecemos na pessoa de seu editor Fernando Sá.

Desejamos a todos/as uma boa leitura! 